\title{
Shi'a and the Tabuik Tradition: A Religious Ritual in Aesthetical Packaging in the Pariaman Community of Minangkabau - West Sumatera
}

\author{
Wilma Sriwulan Andar Indra Sastra \\ Art of Music and Karawitan Study Program, Performing Arts Faculty, Indonesia Institute of the Arts (ISI) \\ Padangpanjang, West Sumatera, Indonesia
}

\begin{abstract}
This article aims to explore Shi'a and the Tabuik Tradition: A Religious Ritual in Aesthetical Packaging in the Pariaman Community of Minangkabau. The presence of Shi'a as a religious sect in Islam cannot be separated from the problem of political conflict in the leadership system. Political conflict caused followers of Islam to break into groups that were for and against a change in Caliph. This conflict of leaderships gave rise to religious sects, each of which claimed to have the rightful successors to continue the Caliphate. Amongst these groups was the Shi'as ect, whose followers tend to be fanatic in their belief that Ali and his descendants inherited the right to Muslim leadership after the death of the Prophet Muhammad. The tabuik is a construction shaped in the form of a winged steed, or buraq, made from a type of bamboo, and used as part of a religious ritual to commemorate the death of Husein ibn Ali in the battle of Karbala in Iraq, on the $10^{\text {th }}$ day of the Muslim month of Muharam. The tabuik ritual is in the form of a colossal drama, or performance, which in the Pariaman community contains an important ideology with a background of religious values or fanaticism, and political values, packaged in an aesthetical form. A qualitative method is used, in which the researcher serves as the instrument for data collection through a literature study, with secondary data in the form of documentation and direct observation in the field. The analysis of the primary data focuses on the tabuik ritual in the Pariaman community of Minangkabau. The research results show that Shi'a and the tabuik tradition have a historical connection with the holy ark (tabut)of the Jewish people. In Pariaman this has become a religious ritual which is packaged aesthetically in the form of a colossal drama.

Keywords: Shi'a; tabuik tradition; religious ritual; aesthetical; Pariaman Minangkabau
\end{abstract}

DOI: $10.7176 / \mathrm{ADS} / 83-07$

Publication date:July $31^{\text {st }} 2020$

\section{INTRODUCTION}

Shi'a (literally meaning followers) is the name of a group of Muslims who are followers and supporters of Ali bin Abi Talib and his family. The emergence of the Shi'asect cannot be separated from the historical and political journey of Muslim leadership in relation to the change of Caliph. These events led to internal conflict amongst Muslims, especially after the death ofthe Caliph Usman bin Afan who was replaced by Ali bin Abi Thalib as the fourth Caliph (in year 661). Ali's appointment as Caliph gave rise to issues of fanaticism; according to H.A.R. Gibb, the views of this sect focus on two matters: (1) Ali's superiority as a successor of the Prophet Muhammad's leadership, which exceeds that of Abu Bakar, Umar bin Khatab, and Usman bin Afan, and (2) the belief that Ali's leadership not only surpasses Abu Bakar, Umar, and Usman, but was also designated by the prophet Muhammad himself according to God's will. (Gibb, 1995: 19). These beliefs were the basis for the emergence of fanaticism amongst Ali's followers who believe that Ali and his descendants hold the right to inherit the leadership of Muslims.

This fanaticism led to a dilemma and internal conflict, which in turn caused the Muslim community to split into groups that were either for or against a change in leadership. This conflict of leadership gave rise to religious sects, each of which claimed the right to succession of the Caliphate. Bahri Yatim states that at the time, Muslims were not satisfied with Ali's leadership and subsequently split into three political forces, namely Mu'awiyah, Shi'a(Ali's followers), and al-Khawarij (Yatim, 1995: 39-42) - (Gibb, 1995: 19).

Furthermore, he states that in the beginning, the last group (al-Khawarij) supported Ali bin Abi Thalib, but later turned against him, considering Ali to be an infidel after accepting arbitration (tahkin) with Mu'awiyah (Yatim, 1995: 42) - (Gibb, 1995: 46). H.A.R. Gibb explains that at that point this group became as the wahabi group which is known for its violent leanings. Muhammad bin Abdul Wahab foundedthe wahabigroup in Saudi Arabia as a movement of Islamic purification which used violence to eradicate bid'ah andkhurafatin the doctrine of Islam. This movement or school of thought was strongly influenced by Ubnu Taimiyyah, a follower of Hambali.Thereafter, Abu Sofyan continued with the Umaiyah dynasty, thus beginning the history of Islamic politics that is divided into the two large groups, Sunni and Shi'a (Gibb, 1995: 44). Fazlur Rahman states that Abu Sofyan continued the Umaiyah dynasty, which was the beginning of the history of Islamic politics with the two large groups, Sunni and Shi'a. The former, according to Fazlur Rahman, assigns real religious authority to consensus (ijmak), and considers a Caliph to be no more than a political and religious executive leader in the community (Rahman, 1992: 276). 
Meanwhile, Shi'adoes not recognize ijmak or consensus, but instead believes in religious leaders as the application of the third pillar of faith (Rahman, 1992: 276). This is reflected in what is written above; especially concerning the views of Shi'a followers regarding the system of leadership that is imbued with a spirit of fanaticism. On this point, H.A.R Gibb writes that in subsequent developments, Shi'a split into severalsects (or parties), including Shi'a imamiyah orShi'a Isna 'Asyariyah, which are still found in Iran today, as well as other more extreme (ghulat) Shi' agroups, some of which believe that God was mistaken in choosing Muhammad and not Ali as His prophet, and even consider Ali to be God (Gibb, 1995: 19). From these conditions, it is clear that the official demands of Ali's descendants were the beginning of the political teachings or ideology of Shi'a.

According to Hamka, the extreme Shi'a sect is referred to as ghulat, which means it has overstepped the boundaries or has greatly exaggerated views. Some members of this sect believe that Ali bin Abi Talib is God (followers of Abdulah bin Saba), also that Jibril was misguided in bringing his revelation. The order from God was for Ali but was mistakenly given to Muhammad. "God was incarnated into the form of five individuals: the prophet Muhammad, Ali, Fatimah, Hasan and Husein. The spirit of God was incarnated in Ali and became one with his body.For this reason, Ali knew all that was a mystery" (Hamka, 1974: 92).

In another section, Hamka writes that the members of this sect are only able to feel joy and devotion in prayer if their foreheads touch a stone that is made fromsoiltaken from the grave of Husein in Karbala, and placed on the ground as they pray. Ibnu Kaldum in Hamka states that they deify their religious leaders, believing that they are human beings with Godly characteristics or that God has been incarnated in these individuals, similar to the Christian belief about Jesus. (Hamka, 1974: 93). Fazlur Rahman also writes that the majority ofShi'aMuslims are followers of the 12 imams, and believe that these imams are incarnations (madhhar)of the original light and that their characters possess divine qualities. However, more extreme muktazilahShi'abelieve that these religious leaders are an incarnation of God and carry the substance of God. Some, such as Ali Illahis, even believe that these imams are literally God (Rahman, 1992: 277).

In connection with this, Rahman explains further that on one hand, making a pilgrimage and worshipping the graves where these imams are buried, and certain other holy places, holds an important place in the religious practices of Shi'a. Large numbers visit Karbala and Mashat with heartfelt sincerity, 'outdoing' the numbers who make the pilgrimage to Mecca. In general, followers of Shi'a Islam have a stronger belief in superstition than Sunnis (Rahman, 1992: 278).

By observing the various characteristics related to the Shi'asect, as described in the section above, it can be said that some of the behaviour of the Shi'a is quite strange when compared with other Muslim groups, and especially Sunni Muslims. This includes their conviction that Ali is a Deity, that God was incarnated into five individuals (see above); even that there was an error in the revelation of Jibril, and the fanatic devotion to Ali and his descendants.

It was this fanaticism thattriggered conflict and led to the bloody events in which Hasan and Husein (sons of Ali bin Abi Talib) were killed. Brockelmann (1952) in Asril states that Husein ibn Ali and his followers were killed by the army of Yazid bin Umaiyah on the battlefield of Karbala, Iraq, in the year 61 Hijriyah (680 AD), specifically in the month of Muharam (Asril, 2015: 68).It is this tragedy surrounding Husein ibn Ali's death that is commemorated every year by Shi'a Muslims in Iran, Iraq, Pakistan, and alsosome Muslim communities in India.These commemorations give rise to acts of excessive fanaticism, in which people lament andwail while beating or torturing themselves while shouting the name of Husein.

These commemorations are also held by Muslims in Indonesia, including Minangkabau, but in different conditions. Because this tragedy was a historical event, every year in the month of Muharam, Muslim preachers talk about this topic in mosques during their Friday sermons. Coinciding with this but in another context, from the first to the tenth day of Muharam, on the west coast of Sumatra (in Bengkulu and Pariaman, West Sumatra), commemorations are held in the form of a ritual ceremony known as tabotortabuik.

In the Pariaman community, the tabuik ritual is a reconstruction of Husein ibn Ali's death in the battle of Karbala, packaged in an aesthetical manner. This aesthetical packaging narrates the series of events symbolically from the first to the tenth of Muharam, beginning with collecting soil, parading the trellis, raising the tabuik, carrying the tabuik along the street, and submerging the tabuik in the sea. This series of events is accompanied by the music of a percussion ensembleknown as gandang tasa. Asril writes that gandang tasa plays a role in various situations and tabuik performances, and creates a "heated" atmosphere, in particular in ritual ceremonies with a dimension of violence, leading to fighting en masse between the different groups oftabuik Does such a ritual give an indication that Shi'a influence is represented in the tabuik tradition? This question will be addressed in this article, with the following topics of discussion: Shi'a tradition and Minangkabau; Shi'a and the tabuik tradition in aesthetical packaging. supporters.

\section{Literature Study}

The literature study in this research can be mapped in two domains: the first domain is related to the understanding of Shi'a and all its problems; the second domain is related to tabuik as a material object. Literature related to Shi'a 
includes the writing of H.A.R. Gibb (1995), which focuses on Ali's superiority as the successor of the leadership of the prophet Muhammad, over that of Abu Bakar, Umar bin Khatab, and Usman bin Afan. Bahri Yatim (1995) discusses the reaction of Muslims who were dissatisfied with Ali's leadership, which resulted in a split into the three large groups Mu'awiyah, Shi'a (followers of Ali), and al-Khawarij. In subsequent developments, Fazlur Rahman (1992) analyzes the conflict in the politics of Muslim leadership which is divided into two main groups, Sunni and Shi'a. Meanwhile, Hamka (1974), a prominent religious figure in Minangkabau, presents his own views on the followers of Shi'a who believe Ali bin Abi Talib to be God (followers of Abdulah bin Saba) - whom he describes asghulat, which means exceeding the boundaries or holding extremely exaggerated views.

On the aspect ofideology, Montgomery Watt (1994) explains that the belief of the Shi' a sect is that theprophet Muhammad's successor who had the right to become the leader (imam) for all Muslims was his cousin and sonin-law, Ali. Shi'a Muslims believe that Ali's rightful successor was his son, Hasan, and Hasan's successor was Husein. Unlike Montgomery Watt, Abdul Qadir Djailani (1996) states that the Shi'a sect is divided into five groups, of which the Numaniyah and Kitabiyahgroups have replaced the Christian concept of the trinity with the fivefold concept of Shi'a, and believe that Muhammad, Fatimah, Ali, Hasan, and Husein together represent God. These five secondary sources are used as the reference for understanding and analyzing the political teachings and emergence of the Shi'a sect, and the indication of any influence of this sect in Minangkabau.

The second domain is literature related to the holy ark (tabut or tabuik); the historical aspect is explored through the special edition ofthe Indonesian Encyclopaedia (1991) and the Indonesian Language Dictionary (Kamus Bahasa Umum Indonesia, Purwadarminta 1984), which offer an understanding of tabut in connection with the prophet Moses. The tabut was so named because it was considered to be a symbol of God's promise to remain faithful to the people of Israel who did not break His word. Meanwhile, Bey Arifin (1971) mentions the existence of the tabut and its connection with the people of Israel since the time of Moses, stating that the tabut gave the people of Israel more courage to face their enemies. Other writers, including Hamka (1974), explain that the existence of the tabut (tabuik) in Pariaman as a religious symbol is related to the events of 10 Muharam on the battlefield of Karbala, and was brought by the Cipai people (from India), the majority of whom were Shi'a Muslims.

Still from the historical perspective, Margaret J. Kartomi (1996) also offers an explanation, that at the end of the $17^{\text {th }}$ century, the British sent Indian Sepoy (Cepai) Troops to Indonesia to build and defend the Marlborough fortress in Bengkulu. From the literature studied in relation to Shi'a and tabut, it is clear that the two complement each other and also that no other writers have discussed this from the perspective of a religious ritual in an aesthetical packaging. Asril (2015), in an article published in JurnalHumanioraentitled "Peran Gandang Tasa Dalam Membangun Semangat dan Suasana Pada Paertunjukan Tabuik Di Pariaman", discusses the important role of gandang tasain arousing the spirit or passion of the supporters of a tabuik performance, which causes the atmosphere to become "heated" and may trigger mass fighting between different groups. Asril (2013), in his articlepublished inJurnal Panggungentitled "PerayaanTabuik danTabot: Jejak Ritual Keagamaan Syia'h di Pesisir Barat Sumatra", in addition to mentioning the origins of the tabuik and tabot celebrations, also discusses the process and influence of the acculturation of the Arabic jazirah culture (from the Middle East) and the local Minangkabau culture. In 2017, in another article Asril talks about the performativity of gandang tasa in the mauluik (maulud) ritual in Sicincin, Pariaman; from an expression of solemnity to one of joy and excitement, loss of control, and trance. The mauluik ritual is performed as part of a religious ritual that combines elements of local culture with traditional music. The traditional music of the gandang tasa (an ensemble of percussion music) is used to create an atmosphere of excitement and to promote a sense of togetherness which leads to a trance.

From the ideological perspective, John Storey (2006) describes ideology as the central concept in a cultural product; this conforms to the conceptual framework of Antonio Gramsci. M. Jazuli (2000) states that functionally, ideology is a collection of ideas and knowledge about goodness which is believed to be true. Meanwhile, in relation to the theory of aesthetics, Manroe Beardsley in The Liang Gie (1983) proposes that in general there are three basic principles of aesthetics [an art event]: (1) unity; (2) complexity; and; (3) intensity. The literature used as a reference for this research enriches the argumentation and is mutually complementary for reaching the goal of the research, as put forward in the title: "Shi'a and the Tabuik Tradition: A Religious Ritual in Aesthetical Packaging in the Pariaman Community of Minangkabau".

\section{Research Method}

A qualitative method supported by secondary data is considered to be suitable and relevant to the focus of this research study. The secondary data in the form of references from various writers is needed to reveal the historical aspect of the emergence of the Shi'a sect and its dissemination and influence in various corners of the world. Likewise, this data is important for revealing the connections between the ark, tabot, and tabuik, which originated from the Jews and subsequently underwent a cultural-religious transformation and became a tradition in the celebration - ritualization - of the 10 Muharam tragedy, specifically in Pariaman, Minangkabau.

The researcher is the main instrument directly responsible for collecting data on the material object - the performance of tabuik in the Pariaman community of Minangkabau. The collection of primary data was carried 
out through participant observation, interviews, and documentation. The primary data obtained through these three models of investigation formed the basis of the analysis in accordance with the focus of the research - Shi'a and the Tabuik Tradition: A Religious Ritual in Aesthetical Packaging.

Participant observation was the first step performed, to observe at first hand the procession of the tabuik performance in Pariaman, Minangkabau, from the first to the tenth of Muharam in the year 2018. The collection of information and empirical data was undertaken through active participation in the performance event, and this was used as the basis for interviewing important figures and heirs of the tabuik tradition in Pariaman.

The second step, in addition to interviews, was documentation through audio-visual and visual media, to support the data and strengthen the argumentation that this event really did take place and was in accordance with its context. Equally important related to the documentation process was its function in helping the writer bring back or recreate the tabuik performance in accordance with its context for the needs of the analysis. The data analysis combines emic and etic concepts to analyze the reality of the tabuik performance in the Pariaman community of Minangkabau as the material object.

\section{RESULT AND DISCUSSION}

1. The Shi'a Tradition and Minangkabau

The Shi'a tradition and Minangkabau are always associated with the tabuik tradition. This 'colossal drama' essentially tells the story of the tragedy of 10 Muharam when the grandson of the prophet Muhammad, Husein ibn Ali, was killed on the battlefield in Karbala, Iraq. The question that arises is whether the tabuik celebration really does originate from the Shi'a tradition. If the answer is no, then why has this tradition developed in the Minangkabau community, specifically in Pariaman, which incidentally has an alliance with the Syatariyah spiritual order? Logically, it is not possible that a certain tradition can develop or be accepted in a community without the presence of a common view related to the Shi'a tradition and all its beliefs, as discussed in the section above.

Western academics are not exaggerating when they say that before the Syafi'i school of thought (encompassing the majority of the Sunnis) spread across Minangkabau, the Shi'a sect or influence was already present. This thesis is proven by the existence of Hasan-Husein tabuik celebrations in a number of cities, such as Padang, Pariaman, and Padangpanjang. This hypothesis is a possibility that may be accepted and has no preclusions causing it to be rejected. However, the evaluation of Western scholars is not entirely accurate. The presence of the Hasan Husein tabuik celebrations does not mean that the people of Minangkabau are followers of the Shi'a school of thought.

As mentioned in the previous section, the Shi'a sect is a group of people who support Ali bin Ali Talib and his family as the rightful successors in the Muslim leadership system. Sunnis, however, consider that the Caliphate is related more to the leadership system in the context of countries, and it is not an absolute rule that the closest members of Muhammad's family must be the Muslim leaders. On the subject of the leadership system, Montgomery Watt explains the views of Shi'a as follows:

The basic belief of all Shi'a sects is that the successor of Muhammad who had the right to become the leader of all Muslims was his cousin Ali, who was also his son-in-law. However, the effective successor of Muhammad, who was appointed Caliph (successor, representative) from the year 632 was Abu Bakar, one of Muhammad's oldest supporters, and he was succeeded by two other leaders, Umar and Usman. Ali eventually became the fourth Caliph in 655 and remained so until he was killed in 661. Shi'a Muslims believe that the rightful successor of Ali was his son, Hasan, and that Hasan's successor was Husein (Watt, 1994: 148).

When the Caliph Umayah passed away in 680, Husein claimed the right to become Caliph, in opposition to Umayah's son, Yazid, but he received little support, and his courageous supporters, consisting of only a hundred or so men, primarily members of Muhammad's 'family', were killed in Karbala when they refused to surrender to the large troops sent by Yazid to intercept them (Watt, 1994: 148). The Shi'asect is explained in more detail by Abdul Qadir Djailani as follows.

The Shi'a sect has five groups:Zaidiyah, Ismailiyah, Istna, ‘Asyariyah (imamiyah), Kaisariyah, and Ghalliyah (Ghulat).The Ghailiyah group, according to Ibnu Kaldum and Sharistani (two well-known Muslim historians) is the Shi'a group that compares the position of Jesus Christ with Muhammad, and specifically with Ali. The groups that are smaller than Ghalliyah, such as Nushairi, believe that Ali is God; the Isyakiyah, Numaniyah, and Kitabiyah groups have replaced the Christian concept of the trinity with the five-fold Shi'a concept, and believe that Muhammad, Fatimah, Ali, Hasan, and Husein together represent God (Djailani, 1996: 150).

The Karbala tragedy is commemorated every year by Shi'a Muslims, and in Minangkabau and Bengkulu these commemorations have been transformed into the form of a colossal drama that is better known as the tabuik or tabot tradition. It is interesting that this tradition is not found either in Iran or Iraq, where the majority of Shi'a communities live. Or at least, there is no religious ritual known as tabuik in these communities. Hamka also explains that in Iran and Iraq, countries following the Shi'a school of thought, there is no such thing as a tabut 
[tabuik and tabot] celebration (Hamka, 1974: 117).

In Iran and Iraq, the commemorations that usually take place on 10 Muharam involve a kind of "demonstration" of mourning in the form of repentance and wailing while beating oneself.Montgomery Watt describes the Shi'a people as being very loyal to their imams or leaders (ahlulbaid), and every year they always commemorate this event with a ceremony of mourning. They believe that Husein died a courageous death and that he had special powers as an intermediary who helps believers to get what they need and hope for, both materially and spiritually (Watt, 1994: 150). This phenomenon has also developed amongst Sufi followers in Minangkabau, and especially in adherents of the Syatariyah order. They believe that spiritually, the position of religious leaders or sheik is always connected to imams or ahlubaid such as Husein, Hasan, and Ali. The fanaticism of these Shi'a followers is such that they use soil taken from the area around Husein's grave to make stones that they use when praying, supposedly to increase their devotion in worship, as explained by Hamka in the previous section.

Returning to the subject of tabuik and tabot, which is purportedly related to the influence of Shi'a in Minangkabau, it can be said that both have the same purpose, namely to commemorate - in a religious ritual - the martyrdom of Husein at the hands of the Yazid army on 10 Muharam. However, what arouses suspicious here is that this kind of tradition does not exist in Iran or Iraq, and this calls for further explanation.

Departing from the understanding of the word tabut (Minangkabau: tabuik; Bengkulu: tabot), in the special edition of the Indonesian Encyclopaedia (Ensiklopedi Indonesia Edisi Khusus) and the Indonesian dictionary (Kamus Bahasa Umum Indonesia) written by Purwadarminta, it states that the word tabut refers to a wooden chest containing two stone tablets, on which are written the Ten Commandments that were given to Moses on Mount Sinai, with a gold lid and two golden cherubim at the ends. This tabut was declared to be holy and placed in the holiest spot in the temple of God. It was called the Ark of the Covenant because it was believed to be a symbol of God's promise to remain faithful to the people of Israel as long as they did not go against His word (Ensiklopedi, 1991: 3115-3116; Purwadarminta, 1984: 989).

In the Qur'an, surahal-Baqarah verse 248, it is written that:“... in truth the sign of His kingdom is that the ark (tabut) comes to you, and inside it is peace from your God and the remnants of the family of Moses and the family of Aaron, carried by angels ...".In the Bible (Old Testament), as quoted by Asril (2013), the Ten Commandments are written as follows:

"(1) Confess the Lord thy God as the only God (tawhid); (2) thou shalt have no other gods before me; (3) thou shalt have no graven images; (4) thou shalt not take the Lord's name in vain; (5) remember the Sabbath day; (6) thou shalt not kill; (7) thou shalt not commit adultery; (8) thou shalt not steal; (9) thou shalt not bear false witness; and (10) thou shalt not covet thy neighbour's belongings (Asril, 2013: 311).

Another version of the Ten Commandments in the Holy Bible, as quoted by Asril (2013) is:

"(1) You shall have no other gods before Me; (2) you shall not make for yourself a carved image of anything that is in the heaven above, in the earth beneath, or in the water under the earth; (3) you shall not take the name of the Lord your God in vain; (4) observe the Sabbath day to keep it holy; (5) honour your father and your mother; (6) you shall not murder; (7) you shall not commit adultery; (8) you shall not steal; (9) you shall not bear false witness against your neighbour; (10) you shall not covet your neighbour's house, which means you shall not covet his wife, his male servant, his female servant, his ox, his donkey, or anything that is your neighbour's (Asril, 2013: 311-312).

In line with what is written in the Purwadarminta's Encyclopaedia, the Quran, an thde Holy Bible, Bey Arifin in his book entitled Rangkaian Cerita dalam Al-Qur'an gives the following explanation.

The ark was an object shaped like a chest, a gift from God which had great significance for the people of Israel from the time of Moses until long after Moses's death. It may be said with regard to this sacred object in the true sense of the word, that when the people of Israel were facing a terrible war or in a precarious situation, if they looked at the ark, they would at once feel peace and steadfastness in their hearts, enabling them to take on and defeat their enemies. Likewise, if there was any conflict between them, by looking at the ark, the dispute between the different groups would at once be resolved and they would again become united. The ark had the ability to give them a spirit of courage and make their enemies weak and afraid (Arifin, 1971: 18).

In line with the above narration about the ark and the Israelites, Karl-Edmund Prier SJ explains how it is described in the Hebrew bible.

In the book of Joshua about the conquering of Jericho, immediately after Joshua spoke to the people, seven priests carrying seven trumpets of ram's horns marched forward before God. Then they blew their trumpets and the ark of the Lord's covenant followed them...then the people shouted while the trumpets were being blown; as soon as the people heard the trumpets sounding, they gave a loud shout (Joshua 6:8-9) - (Prier SJ, 1991: 13). For a clearer picture, see the illustrations of the ark below. 


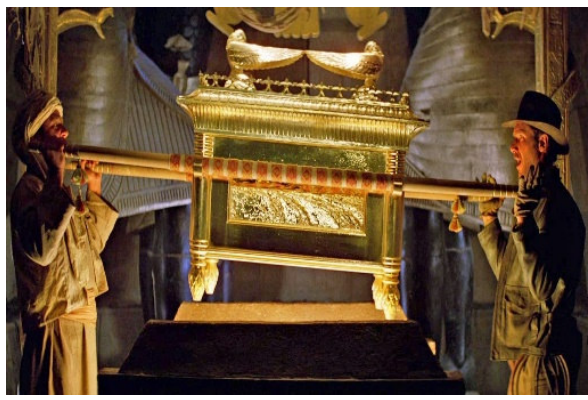

Illustration 1.

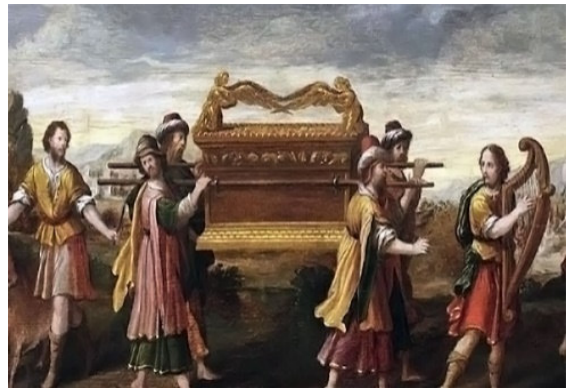

Illustration 2.

\section{https://id.wikipedia.org/wiki/Tabut_Perjanjianhttps://aashyf.blogspot.com/2018/05/tabut-}

18 Nov 2018

the Mosaic covenant

Based on the understanding of the ark and the description given in the excerpt above, it can logically be said that from a historical perspective, the tabut - tabuik and tabot - that has developed in the communities of Minangkabau and Bengkulu is believed to have a connection with the tabut that was used as a symbol of unity amongst the people of Israel through the followers of Shi'a. However, this indication does not mean that members of the Minangkabau community are followers of the Shi' a school of thought. Furthermore, on this subject, it would be good to follow the opinion of Abdul Qadir Djailani, that the originator or founder of the Shi'asect was Abdullah bin Saba (whose name is mentioned in the previous section but has not yet been discussed in detail). Abdullah bin Saba was a Jew from San'a, Yemen, and the son of a black woman. He became a Muslim during the reign of the Caliph Usman bin Afan. He later moved to various places, including Hejes, Basrah, Khufah, Syam, and Egypt (Djailani, 1996: 130).

Institutionally, there is no Shi'a sect in Minangkabau. The indication of this is based on Montgomery's explanation that ranks of religious clergy (ulama), in Iran known as Mullah, are the mujadid, the senior members of which are referred to as Ayatullah (signs of God) - (Watt, 1994: 153). The ulama that Montgomery mentions are not found structurally in Minangkabau. However, various phenomena related to the habits of Shi'a Muslims, such as considering the graves of religious leaders (wali) to be sacred and believing in superstition, are commonplace in Minangkabau, or at least prior to the onset of wahabi influence in 1812. The indication of these phenomena - repeating the words of Fazlur Rahman in the previous section - includes visiting and worshipping at the graves of imams and other holy places, which holds an important place in Shi'a religious practice. In general, Shi'a Muslims also believe more in superstition than Sunnis (Rahman, 1992: 278).

Similarly, Hamka explains in Tuanko Rao that the more prominent characteristics of Shi'a, in terms of their beliefs, are as follows: (1) the call to prayer (azan) includes the phrase "Hayya 'ala khairil 'amal"; (2) in the second Friday prayers, only 'Ali and his descendants' are prayed for. There is no prayer for Abu Bakar, Umar, and Usman, and sometimes some of the companions of the prophet are even cursed; (3) they wail, tear their clothes, slap their cheeks, and beat themselves until they bleed when commemorating the sad day on which Husein was killed in battle at Karbala on 10 Muharam; (4) awaiting the arrival of Imam Mahdi is part of their faith (specifically the $6^{\text {th }}$ pillar of faith); (5) the appointment of Ali bin Abi Talib as Imam (Caliph to the Sunnis) was not chosen by the masses but appointed by the prophet Muhammad himself (Hamka, 1974: 91). These five characteristics mentioned by Hamka are not found in the Minangkabau community, except in the form of the tabuik ritual in Pariaman. In another section, Hamka writes as follows.

On the tradition of the month of Safar, Hamka uses as an example the land of Java. Near to the village of Wonokromo, approximately 13 kilometers from Yogyakarta, is a cave that lies in Mount Permuni. Each year, on the last Wednesday of the month of Safar, crowds of people visit the cave to declare their intentions and vows. According to the belief of the Yogyakarta people, Sultan Agung Hanyokrokusumo had a romantic encounter in this cave with his lover, Nyi Roro Kidul. Similarly, in the village of Jatinom, which lies at a three-way intersection between Solo, Klaten, and Boyolali, on the $15^{\text {th }}$ day of the month of Safar, the community holds a ceremony to commemorate the return of Ki Haji Ageng Gribik after the Hajj pilgrimage on 15 Safar 1511 Saka (1579 AD). On his return to his homeland, because many of his students sought his blessing, he gave out rice flour cakes known as kue apem. This tradition continues to the present day (Hamka, 1974: 83).

Based on the description of Fazlur Rahman in the previous section, similar phenomena are found in Minangkabau, for example in the Basapa activity at the grave of Sheikh Burhanuddin in Ulakan, Pariaman, in which the participants happen to be adherents of the Syatariyah order. In this case, the question that arises is: what is the connection between the Syatariyah order and Shi'a? From the various information provided by Hamka in a polemic with Maharadja Onggang Parlindungan, it is always denied that there is any connection between the basapa [bersyafar] activity and Shi'a teachings, as seen in Hamka's statements that can be quoted from his book Tuanku Rao (Hamka, 1974: 83-84). 
Hamka denies that the activities in the month of Safar are connected to Shi'a teachings, such as in the case of Sheikh Burhanuddin, in which it is said to be coincidental that his death was during the month of Safar (compare this with the events that take place in Java in the same month, as described above - see Hamka 1974: 83). This is understood to be no more than a coincidence. However, it should also be noted that Hamka mentions other overlooked facts, specifically related to the behaviour of the people who tend to regard the graves of religious leaders as holy places, a belief that may lead to superstition, which is a general phenomenon in the Shi'a tradition, as described by Fazlur Rahman (1992: 278) in the previous section.

This subject can be viewed further by looking at the words of Syed Amer Ali in Abdul Qadir Djailani, namely that it is not only the doctrine and teachings of "God's Messengers" in Sufi circles that are the same as those of religious leaders in Shi' a groups [author: the 12 imams], a noble incarnation of God in the world. It should also be noted that almost all Sufi leaders can be traced back to Ali (the first Shi'a imam) - (Djailani, 1996: 34). Similarly, the Syatariyah school of thought in Minangkabau is institutionally not a part of Shi'a tradition, but from the point of view of its spiritual connections, it is related to the highest religious leader of Shi'a, namely Ali. Never theless, it should be emphasized that Ali bin Abi Talib was the fourth Caliph, not the person who invented the teachings of Shi'a.

\section{Shi'a and the Tabuik Tradition in Aesthetical Packaging}

As discussed in the previous section, the existence of the Shi'a tradition in Minangkabau became the subject of a polemic between Maharadja Onggang Parlindungan and Hamka, in particular concerning the existence of Shi'a in Minangkabau.In the opinion of Parlindungan, prior to the introduction of the Syafi'i order of Islam in Minangkabau, which is predominant today, there were already influences of Shi'a Islam. One of the reasons Parlindungan gives for this is the 1800 religious leaders (ulama), known as the Mullah (signs of God). Hamka refutes this and believes it to be untrue, connecting it to the introduction of the wahabi doctrine which led to a complete reform in the religious lives of the Minangkabau people, most of whom could no longer distinguish between religion and shirk (polytheism) combined with superstition, all of which had merged together to become one. This phenomenon has certain similarities with Fazlur Rahman's description above in that Shi'a Muslims tend to believe more in superstition than Sunnis.

Hamka's reasoning is that the total - radical - reform carried out by religious leaders was inspired by the spirit of wahabism in Minangkabau, under the influence of the Hambali school of thought. In reality, the school of thought followed by the Minangkabau community to this day continues to be that of Syafi'i. Based on this condition, Hamka offers the following argument: whatever the religious reforms that took place by reformist wahabi leaders, the remain of old influences would have continued to appear in the Minangkabau community. In reality, however, this is not the case. One indication of this is there are no religious leaders with the title Mullah today in Minangkabau. Compare this with the opinion of Parlindungan, who states that the Shi'a community had existed in Minangkabau for 3 centuries (300 years), only to be wiped out completely in a period of 34 years by reformist leaders inspired by the wahabi doctrine. This is the idiosyncrasy that sparked the intellectual commotion between Hamka and Parlindungan in his book Antara Fakta dan Khayal Tuanku Rao.

There are similar views on the subject of tabuik, which is connected with the tragedy of 10 Muharam and the killing of Husein ibn Ali in Karbala - Iraq-commemorated every year by the people of Minangkabau, specifically on the west coast of West Sumatra, in Pariaman. According to some western scholars, the Hasan Husein tabut celebration is an indication of Shi'a influence in Minangkabau. This hypothesis is certainly a possibility and there is nothing precluding it and causing it to be rejected. However, the interpretation of western scholars is not a final decision which states that the people of Minangkabau are followers of the Shi'a school of thought. In the process of cultural diffusion or acculturation, it is not impossible that this tradition did reach Minangkabau through cultural contact, whether as a result of by political matters or through the lines of trade. What, then, is the nature of the existence of tabuik in Minangkabau? This will be explained in the analysis below.

As Hamka states, in Iraq and Iran, the countries that follow the Shi'a school of thought, there is no such thing as a tabut ([tabuik] celebration. Hamka goes on to deny that in former times the people of Minangkabau were followers of the Shi'a movement because of the tabut celebrations. Hamka writes that at the age of 10, in the kampung of Silaing in Padangpanjang, the local community made a tabut [tabuik], pioneered by a Cipai (Sipahi) man by the name of Gaburan. After the death of Gaburan, there were no more tabut celebrations in Padangpanjang (Hamka 1974: 117). Similarly, Bagindo Muhammad Ramli (1960 in Hamka) also writes that...The Cipai people, who were solders in Pariaman, were the original pioneers of the tabut [tabuik] (Hamka 1974: 118). See the following illustration. 


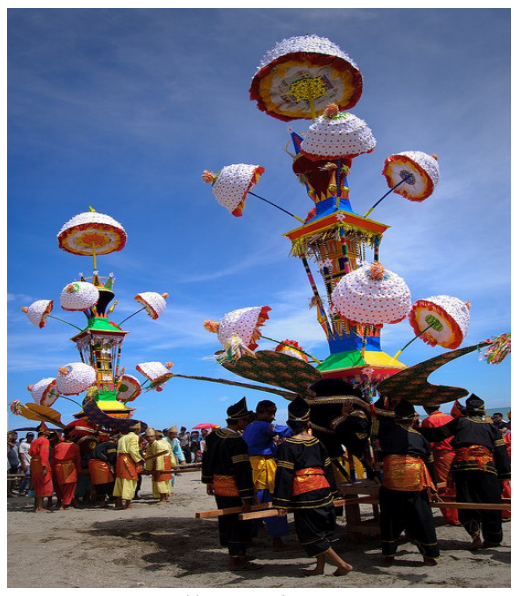

Illustration 3

A tabuik being carried to the sea to be submerged

(Photo: Documentation Arif 2018)

The illustration above shows two tabuik being carried to the edge of the sea to be submerged on the final day of the commemorations. The throwing of the tabuik into the sea is the final part of the religious ritual - colossal drama - of the tabuik performance to commemorate the death of Husein ibn Ali by the Pariaman community in Minangkabau.

Based on Hamka's testimony above, it can be said that the presence of the tabut (tabuik) as a religious symbol is indeed related to the events of 10 Muharam on the battle field of Karbala and was introduced by the Cipai (Indian) community, the majority of whomwere followers of the Shi'a sect. Compare this with the explanation of Margaret J. Kartomi (1986), Tabut - A Shi'a Ritual Transplanted from India to Sumatera, in Nineteenth Century Indonesia, David P. Chandler and M. C. Ricklefs, (ed.), Clayton; Centre of Southeast Asian Studies, Monash University, who writes that from the $16^{\text {th }}$ to the $18^{\text {th }}$ century there was a strong cultural network between Iran and India with the establishment of the Shi'a dynasty in North and South India. At the end of the $17^{\text {th }}$ century, the English sent Indian Sepoy Troops to Indonesia to build and defend the Marlborough Fortress in Bengkulu (Kartomi, 1986: 145). This means that the English soldiers sent from India to Bengkulu were Cipai (Sipahi/Sepoy) Indians belonging to the Shi'a school of thought.

Margaret J. Kartomi's explanation is connected to the statement of Rusli Amran (1980), who writes in his book entitledSumatera Barat dan Palakat Panjang, that according to history, in 1824 the English and Dutch formed a treaty to surrender power of their colonial states. This treaty is known as the London Tract and contained an agreement to surrender Indonesia to the Dutch authorities, with the British subsequently occupying Singapore (Amran, 1980: 267).

Gusfen Kairulalso writes that the London Tract was signed on 17 March 1828, and its agreement included the British giving up Bengkulu to the Dutch while in turn taking over control of Singapore. The English troops, most of whom were Shi'a Cipai Indians fled to the north (to Pariaman). It is these Indians who are said to have brought the tabot from Bengkulu to Pariaman (Khairul: 1983: 4). After the British troops left for Singapore, it is thought that the Cipai Indians broke free from the control of the British. This enabled them to move around freely and earn a living by exploring the west coast of Sumatra, reaching as far as Pariaman, Minangkabau. On the other hand, Margaret J. Kartomi also states that the first person to bring the tabut (tabuik) tradition from India to Bengkulu was a Muslim leader by the name of Senggono, also known as Sheikh Burhanuddin. Subsequently, another religious leader, Kadar Ali, took this tradition to Pariaman (Kartomi, 1986: 142).

Margaret J. Kartomi goes on to say that the traditions of "Asan-Usen" in Aceh or Sura in Java are kinds of rituals that are considered to have a similar spirit and believed to have existed since the first wave of Islam entered Indonesian around the $14^{\text {th }}$ century. Meanwhile, the tabut [tabot and tabuik] tradition in Bengkulu and West Sumatra is thought to have entered with the second wave of Islam towards the end of the $17^{\text {th }}$ century. Unlike the first wave, the second wave did not enter Indonesia directly from the Middle East but via India (Kartomi, 1986: 114). Kartomi's opinion is supported by Hasan (1992) in Asril, who states that the word tabut in this sense is better known in southern parts of India, in particular in Dekkan and Lucknow (Asril, 2013: 312).

From the various descriptions of tabut and tabuik in relation to the Shi'a tradition, it is clear that the Shi'a influence did not come from Iran or Iraq but rather through the Gurkhas (English troops who were Cipai Indians, as described by Kartomi in the previous section), who were Shi'a Muslims. Therefore, it is true to say that the type of Shi'a Islam followed by the Cipai Indians was mixed with the culture of India, a country which upholds values of mysticism and superstition.

This is an interesting phenomenon and one which can academically be used as a consideration of truth. At 
the time when the writer was completing his undergraduate studies at STSI Denpasar, Bali, in 1992, the writer was involved in composing the music for a work choreographed by Novrizal which presented the tabuik tradition in a final assignment. Novrizal was a dance student from Minangkabau, West Sumatra, and the properties used for the dance included a miniature tabuik. When the performance began, the response of the audience - consisting mainly of students from Bali - when they saw the miniature tabuik was to say that in Minangkabau there is also an "ogohogoh" tradition. This meant that when the Balinese people witnessed the tabuik tradition, they considered it to be similar to their own "ogoh-ogoh" tradition, which incidentally originated from the Hindu culture in Bali.

The name ogoh-ogoh itself comes from the Balinese language and means something that is shaken or rocked about. 1983 was an important year in the history of the Balinese ogoh-ogoh because in that year statues of bhuta kala began to be created for the Nyepi ritual in Bali. At that time, a presidential decree was issued which declared Nyepi to be a national holiday. From that time on, the Balinese people began to make large figures called ogohogoh in various places in Denpasar. This new culture became more widespread when the ogoh-ogoh statues were included in the annual Balinese Art Festival, Pesta Kesenian Bali ke XII (see the illustration below).

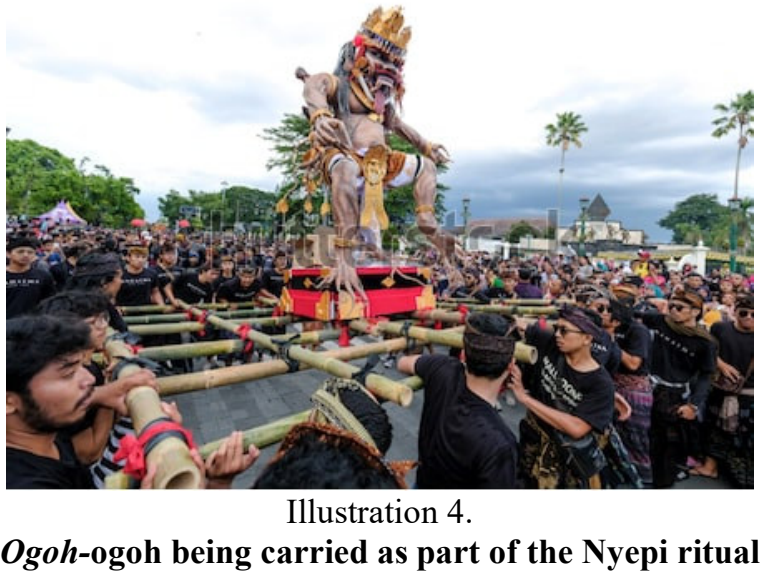

It is this principle of rocking and shaking the structure that is common to both the tabuik and ogoh-ogoh tradition. Therefore, the Balinese people were not mistaken when they thought that Minangkabau also had a tradition of ogoh-ogoh, as described above. Nevertheless, from a philosophical point of view, the tabuik and ogohogoh are different. The philosophical aspect of the tabuik tradition in Pariaman is related to the history of the death of aShi'a imam, Husein ibn Ali, in Karbala by thearmy of Yazin bin Muawiyah, and is narrated in the form of a colossal drama.

What is interesting about this phenomenon is why the people of Minangkabau were willing to accept this tradition despite not being followers of Shi'a. Logically, if there were no cultural similarities, let alone problems concerning religious beliefs, it would seem difficult for the Minangkabau community to adopt a culture from outside. The Minangkabau community's acceptance of the tabuik does not mean that the people were adherents of the Shi'a school of thought but rather due to the fact that the religious message in the tabuik tradition is related to the death of Husein ibn Ali. Despite not being members of the Shi'a sect, the Minangkabau community still recognize the story of Husein ibn Ali as part of their general historical knowledge.

This phenomenon is often presented in the material of Friday sermons, and it is therefore not surprising that the story about tabuik being connected to the tragedy of 10 Muharam in Karbala is accepted by the Minangkabau community. An interesting story is told by Hamka about the Cipai Indians coaxing the local community to help with this event by chipping in to buy paper to make the tabuik or bamboo for the body of the tabuik, because their emotions were touched by the story. Their senses of love and sadness were aroused over the death of Saydina Husein in Karbala, while battling against the "infidel king" by the name of Sultan Bayazid. Subsequently, an old poet by the name of Bagindo Malin wrote a book of poems entitled "The Verse of Hasan-Husein", which he then sang (Hamka 1974: 118).It is known and should be stressed that in general, the narrative related to Hasan-Husein has developed and spread to all corners of Minangkabau.

Aesthetically, the tragedy that afflicted Husein ibn Ali has been packaged in the form of a colossal drama which is known as a tabuik celebration. Martin Suryajaya states that the understanding of aesthetics involves sensory perception: sight, sound, and emotion (Suryajaya, 2015: 1). The dramatic plot of the colossal drama in the form of a tabuik celebration in the Pariaman community combines these three principles of the understanding of aesthetics, as outlined by Suryajaya. Furthermore, he writes that aesthetics not only discuss aesthetical value but also include aesthetical and ontological experiences and the connection between art and the community (Suryajaya, 2015: 1).

The three sensory perceptions Suryajaya mentions accumulate in the tabuik ritual. Visually (the perception of sight) we can witness the sequence in the procession from making the tabuik to submerging it in the sea - from 
the first to the tenth day of Muharam. In terms of the audio-visual perspective (sight and sound), we can hear and also see how the role of the gandang tasa (the percussion ensemble which accompanies the tabuik celebrations) reinforces the expression of sadness and the heroic spirit when the tabuik is carried into the performance arena. Asril et al. write that gandang tasa is the name of a percussion ensemble that has developed significantly in the Pariaman community (in the city of Pariaman and the Padang Pariaman Regency) - (Asril et al, 2018: 58).

In another section, Asril writes that the music of the gandang tasa plays an important role in helping create the various moods of the tabuik performance, including moods of joy, sadness, solemnity, and especially a mood that has a dimension of violence. Meanwhile, the aesthetical value is related to the symbolic - metaphysical meaning of the tabuik which represents the tragedy that afflicted Husein ibn Ali in Karbala on 10 Muharam. The aesthetical-religious experience presented in the procession of the tabuik performance touches on the narration of the events of 10 Muharam, which is retold by the tabuik family in Pariaman. The tabuik performance is not only concerned with ritual alone; from the visual and audio-visual perspectives it also presents elements of beauty, satisfaction, admiration, and so on.

On the form of the performance, Manroe Beardsley, in The Liang Gie, describes 3 characteristics that in general give beauty to an aesthetical object or art event. These characteristics are: (1) unity, in that the dramatic object [event] has a chronology which creates perfection; (2) complexity, in that the dramatic plot is rich in content of elements which oppose each other and combine to create harmony; and (3) intensity, in that the dramatic plot of the art event has a deep level of emotion (Liang Gie, 1983: 48). Manroe's ideas are accumulated in the aesthetical construction - colossal drama - of the tabuik performance in the Pariaman community.

The sense of unity can be seen in the dramatic plot of the tabuik performance, which takes place from 1 to 10 Muharam, as follows: the first day of Muharam begins with collecting soil from the river bed as the evening call to prayer is sung. The soil symbolizes the body of Husein and is placed in a pot and covered with white cloth, then paraded towards a designated place (deraga) that is compared to the grave of Husein, situated next to the home of the tabuik; (2) on the second day of Muharam, the frame or trellis of the tabuik begins to be created; (3) on the fourth day of Muharam, the mystical buraq bird is made. The buraq, which is known to have carried the prophet Muhammad during the Isra and Mi'raj, carried Husein's soul to the heavens; (4) on the fifth day of Muharam, at around 23.00 hours, there is a ceremony to pull out a banana stem. The local market community and the community from the seberang area across the town act like enemies, infiltrating each other's areas to take banana stems that must be broken at the first chop.

The activity described above is an analogy of the counterstrike of Husein's troops against the troops of Yazid in return for the vicious killing of Husein; (5) on the sixth and seventh days of Muharam, ceremonies known as maradai and ma'atam are held to symbolize the collecting of the remains of Husein's body that were scattered in the desert. These remains are then taken and placed in the pot (deraga), to the accompaniment of the gandang tasa (music that accompanies the tabuik procession) which plays 'sad' rhythms; (6) on the eighth day of Muharam, around 5 o'clock in the evening, the frame and remains of Husein's body are carried in procession around the kampung so that the local people can witness the brutality of the Yazid forces, accompanied by the beating of the tasa in rhythmic patterns; (7) on the ninth day of Muharam, there is a parade of Husein's turban which is a symbol of the truth that Husein was defending in battle against the Yazid troops who were attempting to seize the position of Caliph by force. At night, the tabuik makers work hard to prepare the tabuik for the following day; (8) on the tenth day of Muharam, the tabuik is raised onto its platform at 4 o'clock in the morning. It is then carried from the marketplace and the other area across town (seberang) to the main street, complete with all its attributes and in all its grandeur, accompanied by its supporters and the loud percussion music of the gandang tasa, which arouses a spirit of heroism (see the illustration below).

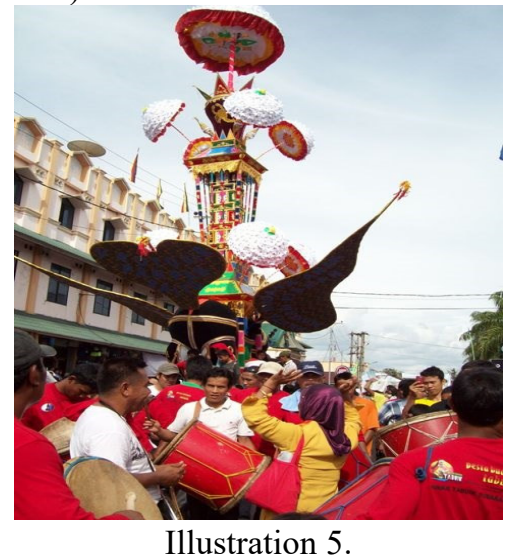

Gandang tasa accompanying the tabuik in the performance arena Photo: Documentation Arif 2018 
Second, the complexity can be witnessed in the dramatic plot of the tabuik performance, combined with the gandang tasa music from the first day of Muharam to the climax on the tenth day. The presence of the gandang tasa music reinforces the expression of every stage of the procession and arouses a spirit of heroism when the tabuik is paraded into the performance arena and immersed into the sea. The connection between the music which is integrated in the series of events in the dramatic plot arouses a spirit of religiosity surrounding the death of Husein ibn Ali at the hands of Yazid bin Muawiyah's army. According to tradition, there are two tabuik groups in the celebrations of 10 Muharam in Pariaman - the tabuik pasa (from the market) and the tabuik subarang (or seberang - literally"across"). Asril writes that the main performers in the tabuik ceremony consist of two groups, each with its own tabuik, namelythe tabuik pasa (market) group, whose activities are centered in Kampuang Perak, Pasir and Pariaman Market (Nagari Pasar Pariaman) and tabuik subarang (seberang), whose activities are centered in Kampuang Pondok, Kampuang Jawa, Kampuang Cina, and Jawi-jawi (Nagari Limo Koto Aia Pampam). The two tabuik portray the two hostile groups, the troops of Husein and Yazid that are engaged in battle in Karbala. The two tabuik are supported by opposing community groups. The opposition of the two groups begins to appear at the beginning of the month of Muharam and throughout the ten days the groups spy on each other and are hostile to one another. This represents the two opposing ideologies of Husein ibn Ali, who represents the family of the prophet Muhammad, and Yazid bin Muawiyah, from the Muawiyah family.

John Storey (2006) in Wilma Sriwulan etal describes ideology as a central concept in a cultural [art] product, and this conforms to the conceptual framework of Antonio Gramsci (Sriwulan et.al, 2018: 52). Philosophically, the narration about the tabuik in its connection with the 10 Muharam tragedy in Karbala contains an ideological recognition of Husein ibn Ali as the leader of Shi'a Muslims. This recognition is manifested in the form of devotion and conviction that Husein is their spiritual leader and the person they hold in great respect. M. Jazuli states that functionally, ideology is a collection of ideas and knowledge about goodness which is believed to be true (Jazuli, 2000: 94). It is true to say that an ideology is a formulation of goals that are aspired to and the means and ways for achieving these goals. This leads to the understanding that an ideology contains intentions that are aspired to.

Third, the intensity of the dramatic plot in the event of the tabuik performance, as described above, from the first to the tenth of Muharam, is seen in the deep emotional appreciation and involvement of the participants. The colossal drama in the tabuik performance displays a battle -psychological conflict. The emotions of the two community groups may even be ignited to the point where they frequently become embroiled in a physical tussle. This fight scene is part of the dramatic plot which represents the battle that took place when the troops of Husein ibn Ali di were killed by the army of Yazid bin Muawiyah in Karbala, Iraq.

\section{CONCLUSION}

Philosophically, the emergence of the Shi'a sect was triggered by the system of replacing the Caliph after the death of the prophet Muhammad. The Shi'aare a group of Muslims who support Ali bin Abi Talib and his family; they recognize him as the de facto and rightful successor in the system of leadership - the Caliph. Politically, the Sunnis view the Caliphate as being related more to the leadership system in the context of the state rather than necessarily the close family of the prophet Muhammad. The tabuik tradition in Pariaman is a construction of the events - the tragedy - of the death of Husein ibn Ali in Karbala, at the hands of the army of Yazid bin Muawiyah.

The tabuik tradition in Pariaman is the legacy of a Shi'a ritual that originated from India. Theologically, the religious doctrine of Shi'a is not found in the Pariaman community of Minangkabau, where the majority of people are followers of the Sunni school of thought (Sunah wal Jamaah). The existence of the tabuik tradition in the Pariaman community does not mean that the people are followers of the Shi'a order; the acceptance of the tabuik tradition in the Pariaman community is sparked by the religious emotions related to the events of the death of Husein ibn Ali at the hands of Yazid bin Muawiyah's army.

The tabuik celebrations in Pariaman are packaged aesthetically in the form of a colossal drama. This colossal drama reconstructs the tragedy of Karbala from the first to the tenth day of Muharam. The narration presented in this tragedy contains the hidden ideology of the Shi'a sect. This ideology steers religious opinion towards the superiority of the Caliph Ali compared with the three previous Caliphs, Abu Bakar Sidiq, Umar bin Khatab, and Usaman bin Afan. Shi'a Muslims believe that the rightful successor of Ali was his son, Hasan, and the successor of Hasan was Husein.

\section{References}

Amran, Rusli. Sumatera Barat dan Palakat Panjang. Jakarta:Sinar Harapan, 1980.

Arifin, Bey. Rangkaian Cerita dalam Al-Qur'an. Surabaya: Alma'arif, 1971.

Asril, "Peran Gandang Tasa Dalam Membangun Semangat dan Suasana Pada Paertunjukan Tabuik Di Pariaman”, Humaniora, Volume 27, No. 1, February 2015, 67-80. "Perayaan Tabuik dan Tabot: Jejak Ritual Keagamaan Islam Shi'a di Pesisir Barat Sumatra, JurnalPanggung, Volume 23, No. 3, September 2013, 310-320.

Asril, and Andar Indra Sastra, Performativity of Gandang Tasa in the Mauluik Ritual in Sicincin, Pariaman, West 
Sumatra, inJurnal Arts and Design Studies, Volume 67, No. 7. 2018, 15-23.

Departemen Pendidikan dan Kebudayaan.Ensiklopedi Indonesia Edisi Khusus.Jakarta:Pusat Perbukuan, 1991.

Djailani, Abdul Qadir. Koreksi Terhadap Ajaran Tasauf. Jakarta:Gema Insani Press, 1996.

Gibb, H.A.R. Modern Trends in Islam.Translated by Machnum Husein.Aliran-Aliran Modern dalam Islam. Jakarta:

PT. Raja Grafindo Persada, 1995.

Gie, The Liang. Garis Besar Estetik: Filsafat Keindahan. 9the Edition. Yogyakarta: Supersukses Publisher, 1983. Hamka.Antara Fakta dan Khayal Tuanku Rao. Jakarta: Bulan Bintang, 1974.

Jazuli, M. Sosiologi Seni. Surakarta: Sebelas Maret University, 2000.

Kartomi, Margaret J. Tabut-A Shi'aRitual Transplanted from India to Sumatera. InNineteenth Century Indonesia,

David P. Chandler and M. C. Ricklefs, (ed.), Clayton; Centre of Southeast Asian Studies, Monash University, 1986.

Kementrian Agama RI, 2010, Al-Quranulkarim. Translated byTafsir Perkata, Bandung: CV Insan Kamil.

Khairul, Gusfen. "Tabuik Piaman”. InHarian Singgalang Minggu, 4 July, Padang, 1993.

Purwadarminta.Kamus Bahasa Umum Indonesia.Jakarta, 1984.

Prier Sj, Karl-Edmund.Sejarah Musik Jilid I. Yogyakarta. Pusat Musik Liturgi, 1991.

Rahman, Fazlur. Islam.Jakarta: Bumi Aksara, 1992.

Watt, Montgomery. Fundamentalis Islam dan Modernitas.Yogyakarta: Hafamira, 1994.

Yatim, Bahri. Sejarah Peradaban Islam.Jakarta: Raja Grafindo, 1995.

Suryajaya, Martin. Sejarah Estetika: Era Klasik Sampai Kontemporer. Jakarta: Gang Kabel, 2015.

Sriwulan, Wilma, Andar Indra Sastra, Firdaus, and Surherni, "Spirituality In The "Battle" Of Two Ideologies In The Performance Of Salawaik Dulang In Minangkabau", Arts and Design Studies, Volume 67. Nomor 7.July 2018, 45-54.

Online References:

https://id.wikipedia.org/wiki/Tabut Perjanjian, 18 Nov 2018.

https://aashyf.blogspot.com/2018/05/tabut-perjanjian-nabi-musa, 18 Nov 2018

http://seputarpengertian.blogspot.com/2017/03/pengertian-ogoh-ogoh-dan-fungsinya.html, downloaded on 27 December 2018.

http://seputarpengertian.blogspot.com/2017/03/pengertian-ogoh-ogoh-dan-fungsinya.html, downloaded on 27 December 2018. 